\title{
Ultrasonic pretreatment of carrot slices: Effects of sonication source on drying kinetics and product quality
}

\author{
BURCIN YILMAZ ${ }^{1,3}$, HULYA CAKMAK ${ }^{2}$ and SEBNEM TAVMAN ${ }^{3}$ \\ ${ }^{1}$ Department of Food Processing, Bogazliyan Vocational High School, Yozgat Bozok University, Yozgat, 66400, Turkey \\ ${ }^{2}$ Department of Food Engineering, Faculty of Engineering, Hitit University, Corum, 19030, Turkey \\ ${ }^{3}$ Department of Food Engineering, Faculty of Engineering, Ege University, Izmir, 35100, Turkey \\ Manuscript received on May 5, 2018; accepted for publication on October 10, 2018
}

\begin{abstract}
How to cite: YILMAZ B, CAKMAK H AND TAVMAN S. 2019. Ultrasonic pretreatment of carrot slices: Effects of sonication source on drying kinetics and product quality. An Acad Bras Cienc 91: e20180447. DOI 10.1590/00013765201920180447.

Abstract: In this study effects of ultrasonic pretreatment with different sonication sources on drying behavior of carrot slices were evaluated. Fresh carrot slices were pretreated with ultrasonic probe at 65 , 75 and $85 \mathrm{~W}$ or ultrasonic bath at 10,20 and $30^{\circ} \mathrm{C}$ for 3,5 and $10 \mathrm{~min}$ before air drying. Water gain $\%$ and solid loss $\%$ of pretreated samples were calculated and color values, $\beta$-carotene content and rehydration ratios of dried samples were determined. Drying behavior of the pretreated samples was evaluated and the drying data were fitted to thin layer drying models. Constant drying rate period was not observed for the carrot slices; however two definite falling-rate periods having different slopes were obtained. Drying time was significantly reduced (up to $20 \%$ ) depending on the type of pretreatment. The redness value, total color difference and Chroma values of pretreated and control samples were in the same group ( $>0.05)$. $\beta$-carotene content of ultrasonic bath pretreated samples were significantly higher than the samples pretreated with ultrasonic probe and the sample dried without any pretreatment as well $(\mathrm{p}<0.05)$. Also rehydration ratios of control samples were found lower than the ultrasound pretreated samples.
\end{abstract}

Key words: Carrot, ultrasound, $\beta$-carotene, rehydration, modelling.

\section{INTRODUCTION}

Carrot (Daucus carota L.) is one of the most consumed vegetable for the nutritional value with its rich vitamin and mineral content (Li et al. 2010). According to USDA national nutrient database for standard reference, 100 grams of fresh carrot (nearly 2 small carrots) includes $835 \mu$ g of Vitamin A RAE (retinol activity equivalent) which is almost

Correspondence to: Burcin Yilmaz

E-mail: burcin.yilmaz@bozok.edu.tr

ORCid: https://orcid.org/0000-0003-0719-4090 equal to the daily recommended amount (NIH 2014, USDA 2014). However, due to its highly perishable nature and being a seasonal vegetable, carrot is dried, canned or pickled in order to extend the shelf life.

In food industry, carrots must be processed prior to its consumption and drying is the fundamental method for preservation especially for instant food industry (Hiranvarachat et al. 2011). Drying process is effective against microbial proliferation in foods by decreasing water activity of the material to be dried and therefore retards 
the physical and chemical changes that may occur during storage (Mayor and Sereno 2004). There is an increasing effort to reduce the post-harvest losses of vegetables and fruits, which is around $30-40 \%$ of total production in developing countries and thus drying process has an important role in agricultural and food industry (Karim and Havlader 2005). Despite being one of the most common methods for food preservation, conventional air-drying is an energy-intense process (Nowacka et al. 2012). To reduce the energy costs some pretreatments can be applied for decreasing the initial water content or modifying the plant tissue structure in a way that helps to shorten the drying time (Fernandes et al. 2008). Blanching, pulsed electric field, high or low pressure applications and osmotic drying methods might be employed for this purpose; however their use is limited since each treatment has some disadvantages on final food quality.

Ultrasound is a sound wave which has a frequency higher than the upper limit of human hearing $(20 \mathrm{kHz})$. The frequency range between $20 \mathrm{kHz}$ and $100 \mathrm{kHz}$ is called as conventional power ultrasound. Ultrasonic waves area series of compression and rarefactions (Mason et al. 2005), which is then causes cavitation by the effect of rarefaction cycles and bubble collapse within the molecules of the applied medium. When the bubble collapses in a liquid system, energy is accumulated (Soria and Villamiel 2010) and this generates local hot spots that has a temperature around $4000 \mathrm{~K}$ and a pressure above $1000 \mathrm{~atm}$ (Mason et al. 2005). The cavitation after bubble collapse creates new microscopic channels in addition to the natural channel that is already within the vegetable tissue which can accelerate the moisture transfer (GarcíaPérez et al. 2007, Feng et al. 2011). Also ultrasonic cavitation helps to release the moisture which is strongly attached and improves the rehydration capacity of the dried food (Feng et al. 2011). For this reason, power ultrasound application as a pretreatment for conventional air drying may reduce the drying time therefore energy costs (Ortuño et al. 2010). The application of ultrasound with ultrasonic probe and ultrasonic baths are discussed individually in the literature; however there are quite a few studies that compares the ultrasound sources and no other study that compares both ultrasonic sources together with the soaking in water pretreatment at same temperature conditions.

The aim of this study was to evaluate differences in drying kinetics of carrot slices pretreated with ultrasonic probe and ultrasonic bath at the frequencies of conventional power ultrasound before air drying. The effect of ultrasound pretreatment on the physical and chemical properties of dried carrot slices including color change, $\beta$-carotene content and rehydration ability were also studied.

\section{MATERIALS AND METHODS}

\section{MATERIALS}

Fresh carrots (Daucus carota L.) were purchased from a local supermarket in Izmir, Turkey and stored in a refrigerator at $4-8^{\circ} \mathrm{C}$ prior to use. The carrots were washed with tap water, then handpeeled and sliced into $3 \pm 0.4 \mathrm{~mm}$ thickness and $3 \pm 0.3 \mathrm{~cm}$ in diameter with an electric slicer (Fresh Express, Moulinex, France). The initial moisture content of the carrot slices was determined using a vacuum oven (WiseVenWOV-30, Daihan Scientific Instruments, Korea $)$ at $70^{\circ} \mathrm{C}(160 \mathrm{~mm} \mathrm{Hg})$ according to AOAC (1998) method no 964.22. Petroleum ether (Merck, Germany), HPLC grade acetone (Sigma-Aldrich, USA) and $\beta$-carotene standard (Sigma-Aldrich, USA) were purchased from local suppliers and used for the analysis of $\beta$-carotene content of fresh and dried carrot samples.

\section{PRETREATMENTS}

Carrot slices were soaked in distilled water (el. conductivity: $9 \mu \mathrm{S} / \mathrm{cm}$ ) instead of tap water due to its stable composition and then subjected to 
ultrasonic waves for 3, 5 and 10 min with two different ultrasonic sources. Control samples were only soaked in distilled water for same periods given in ultrasonic pretreatments to compare the possible effects of sonication. The ratio of water/ sample mass was set to $4: 1(\mathrm{w} / \mathrm{w})$ according to the previous studies given in literature (Nowacka et al. 2012, Abano et al. 2013) and the temperatures were kept constant by circulating distilled water. $75 \mathrm{~g}$ of sample was placed into a glass flask containing 300 $\mathrm{ml}$ distilled water and the flask were then placed into the ultrasonic bath $(24 \times 14 \times 15 \mathrm{~cm}$ interior dimension) (SonorexDigitech DT 103H, Bandelin, Germany) working at a frequency of $35 \mathrm{kHz}$ (140 $\mathrm{W})$. The similar sample preparation procedure was repeated and the ultrasonic probe (UP400S, HielscherUltrasonics GmbH, Germany) working at a frequency of $24 \mathrm{kHz}(\max 400 \mathrm{~W})$ with $\mathrm{H} 14$ sonotrode (14 $\mathrm{mm}$ tip diameter) was placed into the glass flask. Ultrasonic power was set to 65 , 75 and $85 \mathrm{~W}$ and the intensities for those given ultrasound powers were calculated as $42.22,48.72$ and $55.22 \mathrm{~W} \mathrm{~cm}^{-2}$, respectively for the ultrasonic probe $(\mathrm{P})$ and the intensity of ultrasonic bath (B) is $0.42 \mathrm{~W} \mathrm{~cm}^{-2}$. Also, ultrasonic bath (B) and soaking in water $(\mathrm{S})$ experiments were carried out at 10,20 and $30^{\circ} \mathrm{C}$. The sample codes and pretreatment conditions are summarized in Table I. Each pretreatment was performed in triplicate. The samples were immediately taken out of water after the pretreatments and excess water were removed with filter paper before drying. The water gain and solid loss of the pretreated samples were calculated according to the following equations;

$$
\begin{aligned}
& \mathrm{WG}(\%)=\frac{\mathrm{W}_{\mathrm{f}} \mathrm{X}_{f}-\mathrm{W}_{\mathrm{i}} \mathrm{X}_{\mathrm{i}}}{\mathrm{W}_{\mathrm{i}}} \times 100 \\
& \mathrm{SL}(\%)=\frac{\mathrm{W}_{\mathrm{i}}\left(1-\mathrm{X}_{\mathrm{i}}\right)-\mathrm{W}_{\mathrm{f}}\left(1-\mathrm{X}_{\mathrm{f}}\right)}{\mathrm{W}_{\mathrm{i}}\left(1-\mathrm{X}_{\mathrm{i}}\right)} \times 100
\end{aligned}
$$

TABLE I

Pretreatment conditions of carrot slices.

\begin{tabular}{cccc}
\hline $\begin{array}{c}\text { Sample } \\
\text { code }\end{array}$ & $\begin{array}{c}\text { Pretreament } \\
\text { type }\end{array}$ & $\begin{array}{c}\text { Pretreatment } \\
\text { condition }\end{array}$ & $\begin{array}{c}\text { Pretreatment } \\
\text { time (min) }\end{array}$ \\
\hline P65-3 & Ultrasonic probe & $65 \mathrm{~W}$ & 3 \\
P65-5 & Ultrasonic probe & $65 \mathrm{~W}$ & 5 \\
P65-10 & Ultrasonic probe & $65 \mathrm{~W}$ & 10 \\
P75-3 & Ultrasonic probe & $75 \mathrm{~W}$ & 3 \\
P75-5 & Ultrasonic probe & $75 \mathrm{~W}$ & 5 \\
P75-10 & Ultrasonic probe & $75 \mathrm{~W}$ & 10 \\
P85-3 & Ultrasonic probe & $85 \mathrm{~W}$ & 3 \\
P85-5 & Ultrasonic probe & $85 \mathrm{~W}$ & 5 \\
P85-10 & Ultrasonic probe & $85 \mathrm{~W}$ & 10 \\
B10-3 & Ultrasonic bath & $10^{\circ} \mathrm{C}$ & 3 \\
B10-5 & Ultrasonic bath & $10^{\circ} \mathrm{C}$ & 5 \\
B10-10 & Ultrasonic bath & $10^{\circ} \mathrm{C}$ & 10 \\
B20-3 & Ultrasonic bath & $20^{\circ} \mathrm{C}$ & 3 \\
B20-5 & Ultrasonic bath & $20^{\circ} \mathrm{C}$ & 5 \\
B20-10 & Ultrasonic bath & $20^{\circ} \mathrm{C}$ & 10 \\
B30-3 & Ultrasonic bath & $30^{\circ} \mathrm{C}$ & 3 \\
B30-5 & Ultrasonic bath & $30^{\circ} \mathrm{C}$ & 5 \\
B30-10 & Ultrasonic bath & $30^{\circ} \mathrm{C}$ & 10 \\
S10-3 & Soaking in water & $10^{\circ} \mathrm{C}$ & 3 \\
S10-5 & Soaking in water & $10^{\circ} \mathrm{C}$ & 5 \\
S10-10 & Soaking in water & $10^{\circ} \mathrm{C}$ & 10 \\
S20-3 & Soaking in water & $20^{\circ} \mathrm{C}$ & 3 \\
S20-5 & Soaking in water & $20^{\circ} \mathrm{C}$ & 5 \\
S20-10 & Soaking in water & $20^{\circ} \mathrm{C}$ & 10 \\
S30-3 & Soaking in water & $30^{\circ} \mathrm{C}$ & 3 \\
S30-5 & Soaking in water & $30^{\circ} \mathrm{C}$ & 5 \\
S30-10 & Soaking in water & $30^{\circ} \mathrm{C}$ & 10 \\
OD & Dried without & & - \\
pretreatment & Fresh carrot & & - \\
\hline & & & - \\
\hline
\end{tabular}

here WG indicates water gain, SL indicates solid loss percent, $\mathrm{W}$ is weight of sample $(\mathrm{g}), \mathrm{X}$ is moisture content ( $\mathrm{kg}$ water/kg dry matter), $\mathrm{i}$ and $\mathrm{f}$ indices are the initial and final values, respectively.

\section{AIR DRYING}

The carrot samples were air-dried at $60^{\circ} \mathrm{C}$ and with an air velocity $1.2 \mathrm{~ms}^{-1}$ in a laboratory type tray dryer (UOP-8A, Armfield Ltd, Hampshire, UK). Firstly, dryer was preheated to $60^{\circ} \mathrm{C}$ and the carrot slices were placed as a single layer on a wire tray 
$(22 \times 17 \mathrm{~cm})$ and three trays were placed into the racks of the dryer. The air flow was parallel to trays and the drying was carried out approximately $5 \mathrm{~h}$. The samples were weighed with an electronic balance (THB-600, Desis, Turkey) until the samples reached below 9\% moisture on wet basis. Each drying experiment was performed in triplicate. Average sieve load was $1.604 \mathrm{kgm}^{-2}$.

The movement of water inside a solid material can be explained by different mechanisms (Barbosa-Cánovas and Vega-Mercado 1996), but the liquid diffusion theory which is explained by the Fick's second law of diffusion is generally applied to calculate the diffusion coefficients as expressed below;

$\frac{\partial \mathrm{X}}{\partial \mathrm{t}}=D_{\text {eff }} \frac{\partial^{2} \mathrm{X}}{\partial^{2} \mathrm{X}^{2}}$

Equation (3)

here $\mathrm{D}_{\text {eff }}$ is the effective diffusion coefficient, $\mathrm{X}$ is the free moisture content, $\mathrm{t}$ is time and $\mathrm{x}$ is the diffusion path.

When the initial moisture content distribution inside a material is assumed to be uniform and the shrinkage of material is neglected, the analytical solution of Fick's second law for an infinite slab becomes;

$M R=\frac{X-X_{e}}{X_{0}-X_{e}}=\frac{8}{\pi^{2}} \sum_{i=0}^{\infty} \frac{1}{(2 i+1)^{2}} \exp \left[-(2 i+1)^{2} \pi^{2} D_{e f f} \frac{t}{4 L^{2}}\right] \quad$ Equation

Only the first term of this series expressed in equation (4) is employed for longer drying times $\left(\frac{D_{e f f} t}{L^{2}}>0.1\right)$ and the equation is simplified as below; $M R=\frac{X-X_{e}}{X_{0}-X_{e}}=\frac{8}{\pi^{2}} \exp \left[\frac{-\pi^{2} D_{e f f} t}{4 L^{2}}\right]$

Equation (5)

here $\mathrm{X}_{0}$ is initial moisture content $(\mathrm{kg}$ water $/ \mathrm{kg}$ dry matter), $X_{\mathrm{e}}$ is equilibrium moisture content $(\mathrm{kg}$ water $/ \mathrm{kg}$ dry matter), $\mathrm{X}$ is moisture content at time $\mathrm{t}$ ( $\mathrm{kg}$ water/kg dry matter), MR is dimensionless moisture ratio, $\mathrm{L}$ is half thickness $(\mathrm{m})$ of the sample for the materials drying from both sides (Perry and Green 1997).
When $\ln (\mathrm{MR})$ plotted against drying time, the effective diffusion coefficient can be calculated according to the below equation;

$k=\frac{\pi^{2} D_{e f f}}{4 L^{2}}$

Equation (6)

where $\mathrm{k}$ shows the slope of linear segment of the plot.

\section{MATHEMATICAL MODELLING OF DRYING}

Thin layer drying models given in Table II were fitted to experimental drying data for evaluation of the best drying model representing the drying behavior of pretreated carrot slices. Non-linear regression analysis was performed with MATLAB software version 7.7.0 (MathWorks Inc., USA) using curvefitting tool box. Coefficient of determination $\left(\mathrm{R}^{2}\right)$, reduced chi-square $\left(\chi^{2}\right)$ and root mean square error (RMSE) shown in the following equations (Eq. 7, 8 and 9) were obtained for each mathematical model. The mathematical models were evaluated depending on the steps stated in the study of Kucuk et al. (2014) which was; the highest $\mathrm{R}^{2}$ with the lowest $\chi^{2}$ and RMSE were chosen as the best model fitting the experimental data.

$$
\begin{array}{cc}
R^{2}=1-\frac{\sum_{i=1}^{N}\left(M R_{i, e}-M R_{i, p}\right)^{2}}{\left(\sum_{i=1}^{N} M R_{i, e}{ }^{2}\right)-\frac{\left(\sum_{i=1}^{N} M R_{i, e}\right)^{2}}{N}} & \text { Equation (7) } \\
\chi^{2}=\frac{\sum_{Y=1}^{N}\left(M R_{i, e}-M R_{i, p}\right)^{2}}{N-n} & \text { Equation (8) }
\end{array}
$$

$R M S E=\sqrt{\frac{\sum_{i=1}^{N}\left(M R_{i, p}-M R_{i, e}\right)^{2}}{N}} \quad$ Equation (9)

here $\mathrm{MR}_{\mathrm{i}, \mathrm{e}}$ shows experimental dimensionless moisture ratio, $\mathrm{MR}_{\mathrm{i}, \mathrm{p}}$ shows model predicted dimensionless moisture ratio, $\mathrm{N}$ is number of observations, $\mathrm{n}$ is number of constant parameters in the model equation. 
TABLE II

Mathematical models fitted to drying curves.

\begin{tabular}{ccc}
\hline Model name & Model equation & References \\
\hline Lewis & $M R=\exp (-k t)$ & Lewis 1921 \\
$\begin{array}{c}\text { Henderson and } \\
\text { Pabis }\end{array}$ & $M R=\operatorname{aexp}(-k t)$ & $\begin{array}{c}\text { Sonmete et al. } \\
2017\end{array}$ \\
Page & $M R=\exp \left(-k t^{n}\right)$ & Page 1949 \\
Midilli et al. & $M R=a \exp \left(-k t^{n}\right)+b t$ & Midilli et al. 2002 \\
$\begin{array}{c}\text { Modified Midilli } \\
\text { et al. }\end{array}$ & $M R=\exp \left(-k t^{n}\right)+b t$ & $\begin{array}{c}\text { Ghazanfari et al. } \\
2006\end{array}$ \\
\hline
\end{tabular}

COLOR VALUES

The color of fresh and dried carrot slices was measured from the outer flesh part (cortex) with a hand-held chromameter with standard illuminant D65 and $2^{\circ}$ observer (Konica Minolta Sensing Inc, Model: CR400, Japan) with respect to CIE L*,a*, b* color scale. Samples were selected randomly and at least nine readings were recorded for each condition. Chroma $\left(\mathrm{C}^{*}\right)$ and total color difference (TCD) was computed with the following equations;

$$
\mathrm{C}^{*}=\left(\mathrm{a}^{* 2}+\mathrm{b}^{* 2}\right)^{1 / 2}
$$

$\mathrm{TCD}=\left[\left(\mathrm{L}^{*}-\mathrm{L}_{0}^{*}\right)^{2}+\left(\mathrm{a}^{*}-\mathrm{a}_{0}^{*}\right)^{2}+\left(\mathrm{b}^{*}-\mathrm{b}_{0}^{*}\right)^{2}\right]^{1 / 2}$

where $\mathrm{L}_{0}^{*}, \mathrm{a}_{0}^{*}$ and $\mathrm{b}_{0}^{*}$ represents the values of fresh carrot slices.

\section{B-CAROTENE CONTENT}

$\beta$-carotene content of carrots were analyzed according to the study of Ranganna (1986) with some modifications that were stated in the study of Kowalski et al. (2013). $0.4 \mathrm{~g}$ of fresh carrot or $0.05 \mathrm{~g}$ of dried carrot was weighed using an analytical balance (GR-200, AND, USA). $15 \mathrm{ml}$ HPLC grade acetone was added into glass phials containing the carrot samples and left in dark for 24 $\mathrm{h}$. To accelerate the extraction process, solution was homogenized with a laboratory type homogenizer (Ultra-TurraxT25 IKA, Germany) at $12000 \mathrm{rpm}$ for
$1 \mathrm{~min}$. Then the liquid phase was separated from the precipitate and $10 \mathrm{ml}$ petroleum ether, $20 \mathrm{ml}$ distilled water and a pinch of sodium sulfate was added to the liquid extract phase. Liquid phase was separated as acetone-water at the bottom layer and petroleum ether including dye on the upper layer. Absorbance of the etheric phase was read with a spectrophotometer (Varian, Cary $50 \mathrm{UV}-\mathrm{VB}$, USA) at $452 \mathrm{~nm}$. The petroleum ether was used as standard and the experiments were carried out in triplicate. Results are expressed as mg $\beta$-carotene per $100 \mathrm{~g}$ dry matter (carrot).

\section{REHYDRATION RATIO}

Rehydration experiments were carried out at room temperature conditions $\left(20^{\circ} \mathrm{C}\right)$ using distilled water. $2 \mathrm{~g}$ dried carrot slices were placed in a beaker containing of $100 \mathrm{ml}$ of distilled water. Rehydration was carried out for 1, 2, 3 and $4 \mathrm{~h}$ and after the rehydration period ended, water was drained and excess water was removed with filter paper. The analyses were performed in triplicate and rehydration ratio was calculated according to the following equation;

$$
\mathrm{RR}=\frac{\text { Weight after rehydration }(\mathrm{g})}{\text { Weight before rehydration }(\mathrm{g})}
$$

\section{STATISTICAL ANALYSES}

One-way analysis of variance (ANOVA) followed by Duncan's multiple range test using SPSS software version 20.0.0 (IBM, USA) was performed to evaluate differences between the selected parameters. Normal test distribution was checked with Kolmogorov-Smirnov test prior to ANOVA analysis. Level of confidence was $95 \%$ and the results were given as average values.

\section{RESULTS AND DISCUSSION}

\section{THE EFFECT OF PRETREATMENTS ON CARROT SLICES}

Water gain and solid loss percent are illustrated in Table III. There have been some significant 
TABLE III

Water gain, solid loss, $\beta$-carotene and rehydration ratio of the samples.

\begin{tabular}{|c|c|c|c|c|}
\hline Pretreatment & WG (\%) & SL (\%) & $\begin{array}{c}\beta \text {-carotene } \\
\left(\mathrm{mg} \mathrm{100g}^{-1} \mathbf{d m}\right)\end{array}$ & Rehydration ratio* \\
\hline P65-3 & $4.04 \pm 0.02^{\mathrm{e}}$ & $4.10 \pm 0.17^{\mathrm{j}}$ & $66.492 \pm 2.650^{\mathrm{c}, \mathrm{d}, \mathrm{e}}$ & $5.652 \pm 0.127^{\mathrm{a}, \mathrm{b}, \mathrm{c}, \mathrm{d}}$ \\
\hline P65-5 & $4.54 \pm 0.01^{\mathrm{e}, \mathrm{fg} g}$ & $4.15 \pm 0.15^{\mathrm{j}}$ & $81.316 \pm 2.411^{\mathrm{j}, \mathrm{k}}$ & $5.688 \pm 0.123^{\mathrm{a}, \mathrm{b}, \mathrm{c}, \mathrm{d}}$ \\
\hline P65-10 & $5.57 \pm 0.02^{\mathrm{h}, \mathrm{i}}$ & $5.19 \pm 0.18^{1}$ & $80.689 \pm 0.322^{\mathrm{j}, \mathrm{k}}$ & $6.018 \pm 0.126^{\mathrm{d}, \mathrm{e}, \mathrm{f}}$ \\
\hline P75-3 & $5.05 \pm 0.02^{\mathrm{g}, \mathrm{h}}$ & $4.13 \pm 0.17^{\mathrm{j}}$ & $63.941 \pm 0.474^{\mathrm{c}, \mathrm{d}}$ & $5.888 \pm 0.080^{\mathrm{b}, \mathrm{c}, \mathrm{d}, \mathrm{e}, \mathrm{f}}$ \\
\hline P75-5 & $5.56 \pm 0.04^{\mathrm{h}, \mathrm{i}}$ & $5.15 \pm 0.33^{1}$ & $62.817 \pm 1.102^{\mathrm{a}, \mathrm{b}, \mathrm{c}}$ & $5.928 \pm 0.104^{\mathrm{b}, \mathrm{c}, \mathrm{d}, \mathrm{e}, \mathrm{f}}$ \\
\hline P75-10 & $6.03 \pm 0.01^{\mathrm{i}, \mathrm{j}}$ & $6.40 \pm 0.09^{\mathrm{n}}$ & $63.713 \pm 0.145^{\mathrm{b}, \mathrm{c}, \mathrm{d}}$ & $5.983 \pm 0.004^{\mathrm{d}, \mathrm{e}, \mathrm{f}}$ \\
\hline P85-3 & $7.86 \pm 1.00^{1}$ & $3.72 \pm 0.08^{\mathrm{i}}$ & $62.872 \pm 0.123^{\mathrm{a}, \mathrm{b}, \mathrm{c}}$ & $5.528 \pm 0.101^{\mathrm{a}, \mathrm{b}, \mathrm{c}}$ \\
\hline P85-5 & $8.14 \pm 0.07^{1}$ & $4.92 \pm 0.55^{\mathrm{k}}$ & $59.855 \pm 0.805^{\mathrm{a}, \mathrm{b}}$ & $5.993 \pm 0.040^{\mathrm{d}, \mathrm{e}, \mathrm{f}}$ \\
\hline P85-10 & $8.93 \pm 1.08^{\mathrm{m}}$ & $5.64 \pm 0.21^{\mathrm{m}}$ & $69.145 \pm 0.729^{\mathrm{e}, \mathrm{f}}$ & $6.437 \pm 0.137^{\mathrm{g}}$ \\
\hline B10-3 & $4.33 \pm 0.02^{\mathrm{e}, \mathrm{f}}$ & $1.66 \pm 0.06^{\mathrm{d}, \mathrm{e}}$ & $79.346 \pm 1.436^{\mathrm{j}, \mathrm{k}}$ & $6.144 \pm 0.447^{\mathrm{e}, \mathrm{f,g}}$ \\
\hline B10-5 & $4.87 \pm 0.02^{\mathrm{f}, \mathrm{g}}$ & $1.79 \pm 0.09^{\mathrm{e}, \mathrm{f}}$ & $73.507 \pm 2.223^{\mathrm{g}, \mathrm{h}}$ & $5.288 \pm 0.275^{\mathrm{a}}$ \\
\hline B10-10 & $3.35 \pm 0.03^{\mathrm{d}}$ & $3.50 \pm 0.23^{\mathrm{i}}$ & $76.409 \pm 0.269^{\mathrm{g}}$ & $5.489 \pm 0.013^{\mathrm{a}, \mathrm{b}}$ \\
\hline B20-3 & $5.92 \pm 0.04^{\mathrm{i}, \mathrm{j}}$ & $2.06 \pm 0.08^{\mathrm{f,g}}$ & $59.642 \pm 0.028^{\mathrm{a}}$ & $5.948 \pm 0.171^{\mathrm{c}, \mathrm{d}, \mathrm{e}, \mathrm{f}}$ \\
\hline B20-5 & $4.59 \pm 0.02^{\mathrm{e}, \mathrm{f}, \mathrm{g}}$ & $2.31 \pm 0.18^{\mathrm{g}, \mathrm{h}}$ & $66.919 \pm 1.266^{\mathrm{d}, \mathrm{e}}$ & $5.888 \pm 0.289^{\mathrm{b}, \mathrm{c}, \mathrm{d}, \mathrm{e}, \mathrm{f}}$ \\
\hline B20-10 & $6.45 \pm 0.04^{\mathrm{j}, \mathrm{k}}$ & $3.57 \pm 0.16^{\mathrm{i}}$ & $75.009 \pm 0.294^{\mathrm{g}, \mathrm{h}, \mathrm{i}}$ & $5.908 \pm 0.079^{\mathrm{b}, \mathrm{c}, \mathrm{d}, \mathrm{e}, \mathrm{f}}$ \\
\hline B30-3 & $6.98 \pm 0.04^{\mathrm{k}}$ & $2.56 \pm 0.02^{\mathrm{h}}$ & $74.559 \pm 1.297^{\mathrm{g}, \mathrm{h}, \mathrm{i}}$ & $5.811 \pm 0.002^{\mathrm{b}, \mathrm{c}, \mathrm{d}, \mathrm{e}}$ \\
\hline B30-5 & $6.31 \pm 0.05^{\mathrm{j}}$ & $3.56 \pm 0.09^{\mathrm{i}}$ & $78.507 \pm 0.014^{\mathrm{i}, \mathrm{j}, \mathrm{k}}$ & $6.036 \pm 0.184^{\mathrm{d}, \mathrm{e}, \mathrm{f,g}}$ \\
\hline B30-10 & $8.78 \pm 0.09^{\mathrm{m}}$ & $4.45 \pm 0.11^{\mathrm{k}}$ & $81.864 \pm 2.983^{\mathrm{k}}$ & $5.988 \pm 0.185^{\mathrm{d}, \mathrm{e}, \mathrm{f}}$ \\
\hline S10-3 & $1.2 \pm 0.03^{\mathrm{a}}$ & $0.65 \pm 0.17^{\mathrm{a}}$ & $67.037 \pm 1.960^{\mathrm{d}, \mathrm{e}}$ & $5.898 \pm 0.001^{\mathrm{b}, \mathrm{c}, \mathrm{d}, \mathrm{e}, \mathrm{f}}$ \\
\hline S10-5 & $1.97 \pm 0.03^{\mathrm{b}}$ & $0.98 \pm 0.11^{\mathrm{b}}$ & $68.561 \pm 1.960^{\mathrm{e}, \mathrm{f}}$ & $6.047 \pm 0.045^{\mathrm{d}, \mathrm{e}, \mathrm{f}, \mathrm{g}}$ \\
\hline $\mathrm{S} 10-10$ & $2.25 \pm 0.07^{\mathrm{b}}$ & $1.39 \pm 0.11^{\mathrm{c}, \mathrm{d}}$ & $75.129 \pm 0.558^{\mathrm{g}, \mathrm{h}, \mathrm{i}}$ & $6.262 \pm 0.025^{\mathrm{f,g}}$ \\
\hline S20-3 & $1.31 \pm 0.01^{\mathrm{a}}$ & $0.96 \pm 0.07^{\mathrm{b}}$ & $91.968 \pm 0.871^{1}$ & $5.990 \pm 0.387^{\mathrm{d}, \mathrm{e}, \mathrm{f}}$ \\
\hline $\mathrm{S} 20-5$ & $2.51 \pm 0.03^{\mathrm{b}, \mathrm{c}}$ & $1.24 \pm 0.11^{\mathrm{b}}$ & $79.188 \pm 0.700^{\mathrm{i}, \mathrm{k}}$ & $5.882 \pm 0.248^{\mathrm{b}, \mathrm{c}, \mathrm{d}, \mathrm{e}, \mathrm{f}}$ \\
\hline $\mathrm{S} 20-10$ & $2.95 \pm 0.05^{\mathrm{c}, \mathrm{d}}$ & $2.06 \pm 0.15^{\mathrm{f}, \mathrm{g}}$ & $71.502 \pm 2.267^{\mathrm{f}, g}$ & $6.007 \pm 0.096^{\mathrm{d}, \mathrm{e}, \mathrm{f}}$ \\
\hline S30-3 & $2.27 \pm 0.02^{\mathrm{b}}$ & $1.32 \pm 0.02^{\mathrm{c}}$ & $77.290 \pm 1.889^{\mathrm{h}, \mathrm{i}, \mathrm{j}}$ & $5.831 \pm 0.261^{\mathrm{b}, \mathrm{c}, \mathrm{d}, \mathrm{e}, \mathrm{f}}$ \\
\hline S30-5 & $2.58 \pm 0.02^{\mathrm{b}}$ & $1.41 \pm 0.06^{\mathrm{c}, \mathrm{d}}$ & $74.780 \pm 0.150^{\mathrm{g}, \mathrm{h}, \mathrm{i}}$ & $6.000 \pm 0.191^{\mathrm{d}, \mathrm{e}, \mathrm{f}}$ \\
\hline $\mathrm{S} 30-10$ & $4.28 \pm 0.03^{\mathrm{f}}$ & $2.04 \pm 0.03^{\mathrm{f}, \mathrm{g}}$ & $73.424 \pm 3.367^{\mathrm{g}, \mathrm{h}}$ & $5.905 \pm 0.202^{\mathrm{b}, \mathrm{c}, \mathrm{d}, \mathrm{e}, \mathrm{f}}$ \\
\hline OD & - & - & $59.251 \pm 0.424^{\mathrm{a}}$ & $5.509 \pm 0.156^{\mathrm{a}, \mathrm{b}, \mathrm{c}}$ \\
\hline $\mathrm{FC}$ & - & - & $99.837 \pm 0.736^{\mathrm{m}}$ & - \\
\hline
\end{tabular}

*Represents the ratio at the end of rehydration period ( $4^{\text {th }}$ hour);

${ }^{a-n}$ Different superscripts in the same column are significantly different $(p<0.05)$.

changes between samples in terms of soluble solid content and water content of pretreated carrot slices $(p<0.05)$. According to average percent solid loss content, the highest values were observed for the longest pretreatment time. However, there was no significant difference observed between $10 \mathrm{~min}$ treatment with $85 \mathrm{~W}$ ultrasonic probe (P85-10) and ultrasonic bath at $30^{\circ} \mathrm{C}(\mathrm{B} 30-10)$. Depending on the pretreatment time, $\mathrm{WG} \%$ increased with increasing power of ultrasonic probe pretreatment. Also the samples soaked in distilled water had the lowest water gain values at shorter pretreatment periods. At similar water temperatures, the samples pretreated with ultrasonic bath had significantly higher water gain values. For solid loss, the lowest values were observed for soaking in water at $10^{\circ} \mathrm{C}$ for $3 \mathrm{~min}(\mathrm{~S} 10-3)$ and the highest value were obtained from $75 \mathrm{~W}$ ultrasonic probe treatment for 
10 min (P75-10). As it can be noticed, increasing pretreatment time caused an increment in solid loss. At same frequency and pretreatment time, comparably higher water gain and lower solid loss were observed for carrot cubes in the study of Abano et al. (2013). Although the applied power with ultrasonic probe is quite lower than the present study, similar results were obtained for ultrasonically pretreated guava drying in the study of Kek et al. (2013). As a result of these observations, ultrasonic pretreatments have significant effects on the vegetable tissue and possibly change the porous structure of the vegetable.

\section{DRYING KINETICS}

The carrot slices which had an average moisture content of $88.93 \pm 0.52 \%$ and equilibrium moisture content of $0.0775 \pm 0.0055 \mathrm{~kg}$ water $/ \mathrm{kg} \mathrm{dm}$ were dried after pretreatments until the final moisture content of $9 \%$ wet basis. For agricultural and food materials, the moisture ratio is to be reduced under $10 \%$ in order to prevent microbial growth, reduce chemical and enzymatic reactions that may negatively affect the dried product quality. Drying time to reach the specified moisture content is given in Table IV and sample drying curves of different pretreatments are presented in Figure 1. The sample which was only dried without any pretreatment (OD) had the highest drying time with an average of $246 \pm 8.52 \mathrm{~min}$. The samples having the highest water gain values (P85-10 and B3010) reached below the $9 \%$ moisture content faster than the sample without pretreatment. There was no significant difference observed for drying time of ultrasonic pretreated samples ( $p>0.05$ ); however the control samples that were soaked in distilled water needed longer drying time to reach the same moisture content. When the results of pretreated samples were compared, drying time was reduced between 8.5 to $20.5 \%$ depending on pretreatment method. These results indicated the damaging effect of ultrasound on the tissue of the carrot

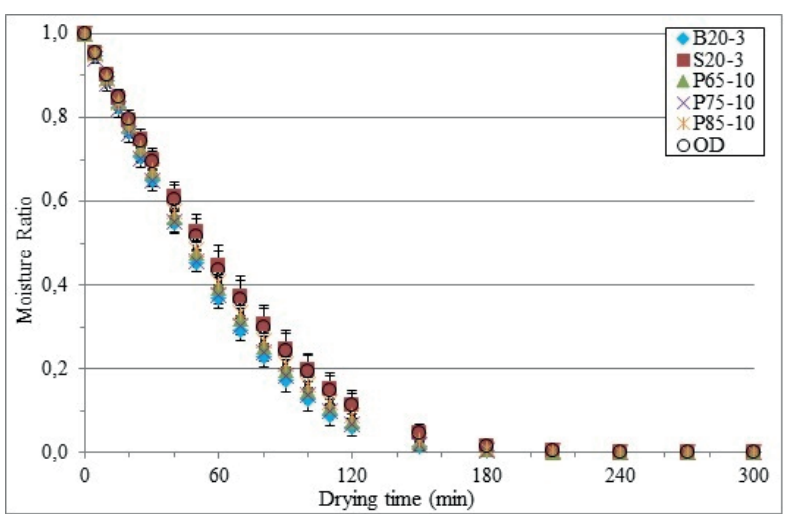

Figure 1 - Drying curves of carrot slices.

slices as it was expressed in the study of Jambrak et al. (2007) and Nowacka et al. (2012) depending on compression and rarefaction -sponge effectphenomenon of ultrasonic waves. In the study of Abano et al. (2013), it was stated that the drying time of carrot cubes was reduced nearly $50 \%$ depending on the ultrasonic pretreatment at $32 \mathrm{kHz}$ for a comparably longer application period than the present study.

The effective diffusion coefficients that were calculated according to simplified Fick's second law for slab are shown in Table IV. Initially, the assumption used for simplification of this law $\left(\frac{D_{e f f} t}{L^{2}}>0.1\right)$ even at lower values of effective diffusion coefficients was justified. For all dried samples independent of pretreatment type, only fallingrate period was observed. Besides, the falling-rate period was observed with two different slopes in the drying rate curves, which then led us to divide the drying curves into two parts for calculating the different effective diffusion coefficients. The highest $\mathrm{D}_{\text {eff }}$ of the both falling-rate periods were observed for the sample pretreated with ultrasonic probe at $65 \mathrm{~W}$ for $10 \mathrm{~min}$, while the lowest value was observed for the sample without pretreatment (OD). The relation between applied ultrasound power and effective diffusion coefficients were not clear and statistically different for each of the pretreatments, on the other hand ultrasonic pretreated samples had higher diffusion coefficients compared to the 
TABLE IV

Effective diffusion coefficients and drying time of the samples.

\begin{tabular}{|c|c|c|c|}
\hline Sample & $\mathrm{D} \times 10^{10}\left(\mathrm{~m}^{2} \mathrm{~s}^{-1}\right)^{1}$ & $\mathrm{D} \times 10^{10}\left(\mathrm{~m}^{2} \mathrm{~s}^{-1}\right)^{2}$ & Drying time(min)* \\
\hline P65-3 & $2.93^{\mathrm{a}, \mathrm{b}, \mathrm{c}}$ & $5.92^{\mathrm{b}, \mathrm{c}}$ & $198 \pm 2.94^{\mathrm{a}, \mathrm{b}}$ \\
\hline P65-5 & $2.97^{\mathrm{ab}, \mathrm{c}}$ & $5.69^{\mathrm{a}, \mathrm{b}, \mathrm{c}}$ & $200 \pm 2.82^{\mathrm{a}, \mathrm{b}}$ \\
\hline P65-10 & $3.27^{\mathrm{c}}$ & $6.17^{\mathrm{c}}$ & $195 \pm 3.26^{\mathrm{a}}$ \\
\hline P75-3 & $3.04^{\mathrm{a}, \mathrm{b}, \mathrm{c}}$ & $5.59^{\mathrm{a}, \mathrm{b}, \mathrm{c}}$ & $196 \pm 8.48^{\mathrm{a}}$ \\
\hline P75-5 & $3.12^{\mathrm{b}, \mathrm{c}}$ & $5.38^{\mathrm{a}, \mathrm{b}, \mathrm{c}}$ & $203 \pm 3.53^{\mathrm{a}, \mathrm{b}, \mathrm{c}}$ \\
\hline P75-10 & $2.98^{\mathrm{a}, \mathrm{b}, \mathrm{c}}$ & $5.55^{\mathrm{a}, \mathrm{b}, \mathrm{c}}$ & $210 \pm 4.82^{\mathrm{a}, \mathrm{b}, \mathrm{c}, \mathrm{d}, \mathrm{e}, \mathrm{f}, \mathrm{g}, \mathrm{h}}$ \\
\hline P85-3 & $2.60^{\mathrm{a}, \mathrm{b}}$ & $5.65^{\mathrm{a}, \mathrm{b}, \mathrm{c}}$ & $209 \pm 1.41^{\mathrm{a}, \mathrm{b}, \mathrm{c}, \mathrm{d}, \mathrm{e}, \mathrm{f}, \mathrm{g}}$ \\
\hline P85-5 & $2.91^{\mathrm{a}, \mathrm{b}, \mathrm{c}}$ & $5.61^{\mathrm{a}, \mathrm{b}, \mathrm{c}}$ & $217 \pm 11.31^{\mathrm{c}, \mathrm{de}, \mathrm{e}, \mathrm{g}, \mathrm{h}, \mathrm{i}}$ \\
\hline P85-10 & $2.86^{\mathrm{a}, \mathrm{b}, \mathrm{c}}$ & $5.57^{\mathrm{a}, \mathrm{b}, \mathrm{c}}$ & $203 \pm 0.71^{\mathrm{a}, \mathrm{b}, \mathrm{c}}$ \\
\hline B10-3 & $2.66^{\mathrm{a}, \mathrm{b}}$ & $5.42^{\mathrm{a}, \mathrm{b}, \mathrm{c}}$ & $200 \pm 2.82^{\mathrm{a}, \mathrm{b}}$ \\
\hline $\mathrm{B} 10-5$ & $2.82^{\mathrm{a}, \mathrm{b}, \mathrm{c}}$ & $5.04^{\mathrm{a}}$ & $213 \pm 9.89^{\mathrm{b}, \mathrm{c}, \mathrm{d}, \mathrm{e}, \mathrm{f}, \mathrm{g}, \mathrm{h}, \mathrm{i}}$ \\
\hline B10-10 & $2.63^{\mathrm{a}, \mathrm{b}}$ & $5.45^{\mathrm{a}, \mathrm{b}, \mathrm{c}}$ & $226 \pm 2.05^{\mathrm{i}}$ \\
\hline B20-3 & $2.90^{\mathrm{a}, \mathrm{b}, \mathrm{c}}$ & $5.64^{\mathrm{a}, \mathrm{b}, \mathrm{c}}$ & $203 \pm 3.55^{\mathrm{a}, \mathrm{b}, \mathrm{c}, \mathrm{d}}$ \\
\hline B20-5 & $3.09^{\mathrm{a}, \mathrm{b}, \mathrm{c}}$ & $5.68^{\mathrm{a}, \mathrm{b}, \mathrm{c}}$ & $204 \pm 5.65^{\mathrm{a}, \mathrm{b}, \mathrm{c}, \mathrm{d}, \mathrm{e}}$ \\
\hline B20-10 & $2.99^{\mathrm{a}, \mathrm{b}, \mathrm{c}}$ & $5.71^{a, b, c}$ & $207 \pm 3.53^{\mathrm{a}, \mathrm{b}, \mathrm{c}, \mathrm{d}, \mathrm{e}, \mathrm{f}}$ \\
\hline B30-3 & $2.70^{\mathrm{a}, \mathrm{b}}$ & $6.04^{\mathrm{c}}$ & $205 \pm 4.24^{\mathrm{a}, \mathrm{b}, \mathrm{c}, \mathrm{d}, \mathrm{e}}$ \\
\hline B30-5 & $2.83^{\mathrm{a}, \mathrm{b}, \mathrm{c}}$ & $5.66^{\mathrm{a}, \mathrm{b}, \mathrm{c}}$ & $205 \pm 0.71^{\mathrm{a}, \mathrm{b}, \mathrm{c}, \mathrm{d}, \mathrm{e}}$ \\
\hline B30-10 & $2.75^{\mathrm{a}, \mathrm{b}, \mathrm{c}}$ & $5.56^{\mathrm{a}, \mathrm{b}, \mathrm{c}}$ & $213 \pm 7.07^{\mathrm{b}, \mathrm{c}, \mathrm{d}, \mathrm{e}, \mathrm{f}, \mathrm{g}, \mathrm{h}, \mathrm{i}}$ \\
\hline $\mathrm{S} 10-3$ & $2.94^{\mathrm{a}, \mathrm{b}, \mathrm{c}}$ & $5.95^{\mathrm{b}, \mathrm{c}}$ & $217 \pm 1.41^{\mathrm{c}, \mathrm{d}, \mathrm{e}, \mathrm{f}, \mathrm{g}, \mathrm{h}, \mathrm{i}}$ \\
\hline $\mathrm{S} 10-5$ & $2.95^{\mathrm{a}, \mathrm{b}, \mathrm{c}}$ & $5.61^{\mathrm{a}, \mathrm{b}, \mathrm{c}}$ & $219 \pm 5.65^{\mathrm{e}, \mathrm{fg}, \mathrm{h}, \mathrm{i}}$ \\
\hline S10-10 & $2.81^{\mathrm{a}, \mathrm{b}, \mathrm{c}}$ & $5.46^{\mathrm{a}, \mathrm{b}, \mathrm{c}}$ & $218 \pm 10.60^{\mathrm{c}, \mathrm{de}, \mathrm{ef}, \mathrm{g}, \mathrm{h}, \mathrm{i}}$ \\
\hline $\mathrm{S} 20-3$ & $2.94^{\mathrm{a}, \mathrm{b}, \mathrm{c}}$ & $5.64^{\mathrm{a}, \mathrm{b}, \mathrm{c}}$ & $213 \pm 10.60^{\mathrm{b}, \mathrm{c}, \mathrm{d}, \mathrm{e}, \mathrm{f}, \mathrm{g}, \mathrm{h},}$ \\
\hline $\mathrm{S} 20-5$ & $2.74^{\mathrm{a}, \mathrm{b}}$ & $5.40^{\mathrm{a}, \mathrm{b}, \mathrm{c}}$ & $218 \pm 2.82^{\mathrm{d}, \mathrm{e}, \mathrm{f}, \mathrm{g}, \mathrm{h}, \mathrm{i}}$ \\
\hline S20-10 & $2.76^{\mathrm{a}, \mathrm{b}, \mathrm{c}}$ & $5.50^{\mathrm{a}, \mathrm{b}, \mathrm{c}}$ & $225 \pm 1.41^{\mathrm{h}, \mathrm{i}}$ \\
\hline $\mathrm{S} 30-3$ & $2.87^{\mathrm{a}, \mathrm{b}, \mathrm{c}}$ & $5.30^{\mathrm{a}, \mathrm{b}, \mathrm{c}}$ & $224 \pm 6.36^{\mathrm{g}, \mathrm{h}, \mathrm{I}}$ \\
\hline $\mathrm{S} 30-5$ & $2.91^{\mathrm{a}, \mathrm{b}, \mathrm{c}}$ & $5.49^{\mathrm{a}, \mathrm{b}, \mathrm{c}}$ & $221 \pm 4.94^{\mathrm{f}, \mathrm{g}, \mathrm{h}, \mathrm{i}}$ \\
\hline $\mathrm{S} 30-10$ & $2.81^{\mathrm{a}, \mathrm{b}, \mathrm{c}}$ & $5.65^{a, b, c}$ & $221 \pm 5.82^{\mathrm{f}, \mathrm{g}, \mathrm{h}, \mathrm{i}}$ \\
\hline OD & $2.57^{\mathrm{a}}$ & $5.10^{\mathrm{a}, \mathrm{b}}$ & $246 \pm 8.52^{\mathrm{j}}$ \\
\hline
\end{tabular}

${ }^{1}$ indicates first falling rate period, ${ }^{2}$ indicates second falling rate period;

*Time to reach below $9 \%$ moisture content;

${ }^{\mathrm{a}-\mathrm{j}}$ Different superscripts in the same column are significantly different $(\mathrm{p}<0.05)$.

sample without pretreatment similar to the recent studies (García-Noguera et al. 2010, Ortuño et al. 2010, García-Pérez et al. 2011).

\section{MATHEMATICAL MODELLING OF DRYING}

Thin layer drying approach is quite popular for drying of agricultural products, since the mathematical models given in the literature can give a quick response without any drying application.
Therefore, valuable sources such as material and energy are not wasted for the data collection.

Thin layer modelling data for carrot drying can be found in literature in various sample shapes (cube, disc, slab) and different drying conditions (air temperature, air velocity, relative humidity) (Doymaz 2004, Aghbashlo et al. 2009, Li et al. 2010, Abano et al. 2013, Sonmete et al. 2017), however thin layer modelling of ultrasound pretreated carrot drying was not common. 
Especially this present research will provide comparative data for ultrasonic source selection for future studies.

Mathematical models shown in Table II were fitted to experimental drying data of carrot slices, and the results are summarized in Tables $\mathrm{V}$ and VI. Midilli et al. model was the best model giving the highest $\mathrm{R}^{2}$ with the lowest $\chi^{2}$ and RMSE for almost each pretreatment condition; however $\mathrm{R}^{2}$ was found higher than 0.98 for the rest of the fitted models. Sonmete et al. (2017) have studied on drying of carrot slices at 55,65 and $75^{\circ} \mathrm{C}$ with air velocities of 2 and $3 \mathrm{~m} \mathrm{~s}^{-1}$ without any pretreatment and best fitting model for drying data was similarly indicated as Midilli et al. model. Depending on the literature, Page model and Henderson and Pabis models were employed for representation of thin layer carrot drying (Doymaz 2004, Aghbashlo et al. 2009, Zielinska and Markowski 2010).

\section{THE EFFECT OF PRETREATMENT ON}

DEHYDRATED CARROT COLOR

The average of color values of all carrot samples was listed in Table VII. Whiteness ( $\left.\mathrm{L}^{*}\right)$ values of all dried carrot samples were significantly different compared to the fresh sample $(\mathrm{p}<0.05)$, while S2010 and P85-5 had the highest $\mathrm{L}^{*}$ values among them. However ultrasonic pretreatment increased whiteness value while reducing yellowness value, and had almost no significant effect on redness value $(p>0.05)$. The decrease in redness value is stated as an indicator of heat degradation of carotenoids during drying (Stojanovic and Silva 2007), but due to enzymatic browning during the drying process, an increase in redness may also be observed. In a study, the redness of ultrasonic bath $(21 \mathrm{kHz})$ pretreated dried apples were found significantly higher compared to the untreated dried apples (Fijalkowska et al. 2016). In carrots, most of the pretreated samples were in the same group with the fresh sample, so the redness was remained similar to the original value before drying.
The highest redness value was observed for the sample without pretreatment, also the yellowness and the $\mathrm{C}^{*}$ value was yet higher than the rest of the samples. $\mathrm{C}^{*}$ values that corresponds to degree of paleness were lowest for pretreated samples and also pretreatment time increased the paleness by decreasing the $\mathrm{C}^{*}$ values. This may be linked to the solid loss may lead to the loss of color compounds as well. Total color difference (TCD) demonstrates the mutual effect of whiteness, redness and yellowness and among all samples, the lowest change in TCD was found in B30-5 and B30-10. The highest TCD value was obtained in P85-5 and thus this pretreatment can be entitled as the mildest treatment with respect to the highest change in color.

\section{B-CAROTENE CONTENT}

$\beta$-carotene is one of the hydrocarbon carotenoids and is converted into vitamin $\mathrm{A}$ in the human body (Hiranvarachat et al. 2011). The intensity of yellow color in vegetables is usually associated with the higher $\beta$-carotene content. It gives carrot its characteristic orange color; however this compound is sensitive to heat, light, oxygen and enzymes (Kowalski et al. 2013).

The average $\beta$-carotene content of the fresh carrot was found as $99.837 \mathrm{mg} / 100 \mathrm{~g}$ dry matter and $59.251 \mathrm{mg} / 100 \mathrm{~g}$ dry matter for the sample dried without pretreatment as shown in Table II. The amount of $\beta$-carotene was significantly different for pretreated samples when they were compared altogether $(p<0.05)$; although the effects were not similar depending on each pretreatment type. $\beta$-carotene contents of each pretreatment types depending on the process time and power level/ temperature were statistically compared, however the data are not shown in Table III for avoiding any confusion. $\beta$-carotene retention of the samples pretreated with ultrasonic probe at $65 \mathrm{~W}$ improved with increasing the process time, although the similar effect was not observed for the other power 


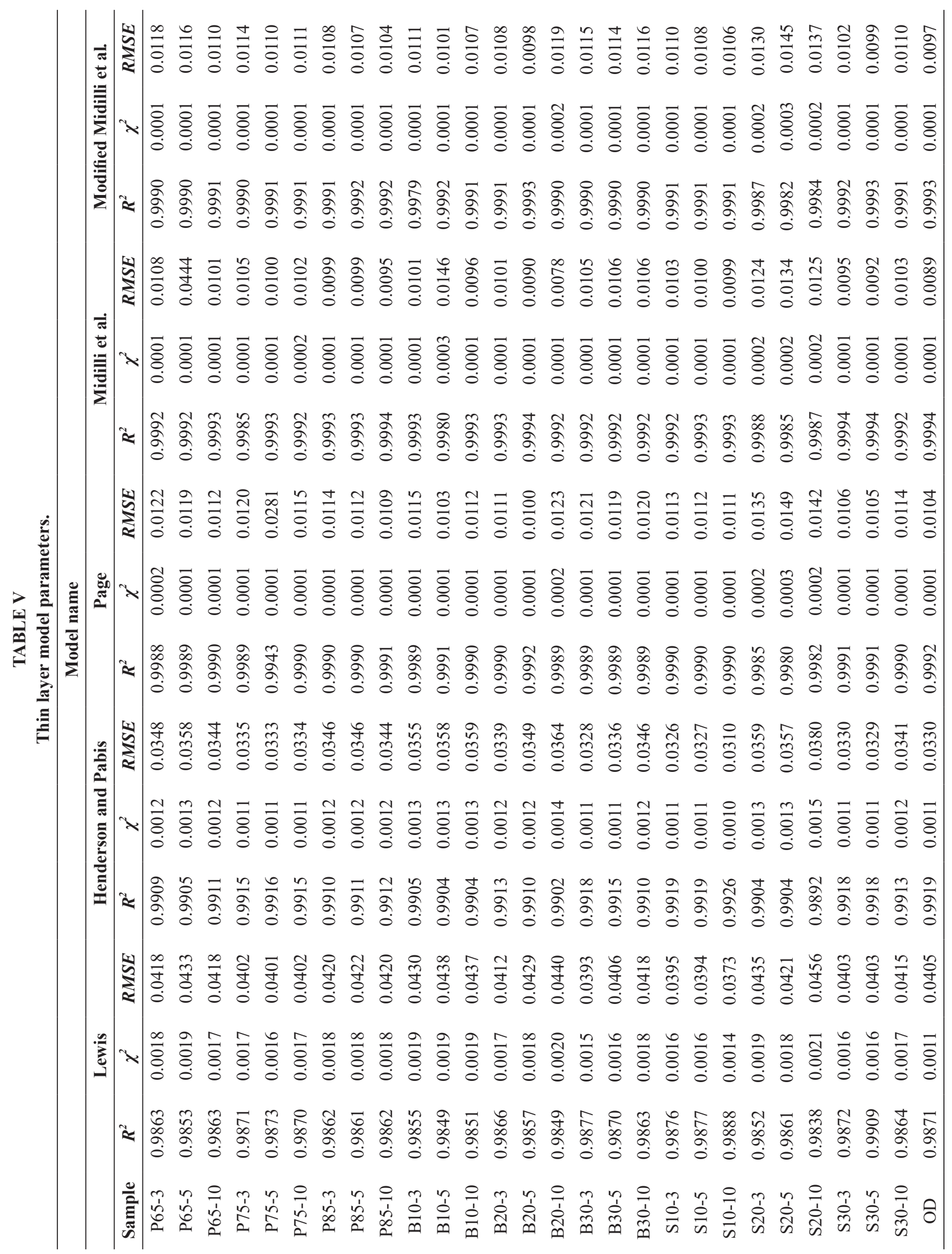


TABLE VI

Model coefficients for Midilli et al. (2002).

\begin{tabular}{ccccc}
\hline & \multicolumn{4}{c}{ Model coefficients } \\
\hline Sample & $\mathbf{a}$ & $\mathbf{k}$ & $\mathbf{n}$ & $\mathbf{b}$ \\
\hline P65-3 & 0.9825 & 0.004328 & 1.3103 & $-2.75 \times 10^{-5}$ \\
P65-5 & 0.9832 & 0.004150 & 1.3226 & $-2.63 \times 10^{-5}$ \\
P65-10 & 0.9843 & 0.004699 & 1.3090 & $-2.29 \times 10^{-5}$ \\
P75-3 & 0.9831 & 0.004637 & 1.2946 & $-2.93 \times 10^{-5}$ \\
P75-5 & 0.9833 & 0.004765 & 1.2967 & $-2.42 \times 10^{-5}$ \\
P75-10 & 0.9836 & 0.004923 & 1.2970 & $-2.54 \times 10^{-5}$ \\
P85-3 & 0.9841 & 0.004208 & 1.3080 & $-2.95 \times 10^{-5}$ \\
P85-5 & 0.9846 & 0.004219 & 1.3093 & $-2.75 \times 10^{-5}$ \\
P85-10 & 0.9848 & 0.004253 & 1.3070 & $-2.82 \times 10^{-5}$ \\
B10-3 & 0.9832 & 0.004238 & 1.3213 & $-2.64 \times 10^{-5}$ \\
B10-5 & 0.9825 & 0.004763 & 1.2886 & $-3.56 \times 10^{-5}$ \\
B10-10 & 0.9833 & 0.003871 & 1.3266 & $-2.74 \times 10^{-5}$ \\
B20-3 & 0.9847 & 0.004680 & 1.3030 & $-2.55 \times 10^{-5}$ \\
B20-5 & 0.9860 & 0.004397 & 1.3180 & $-2.10 \times 10^{-5}$ \\
B20-10 & 0.9828 & 0.003949 & 1.3276 & $-2.92 \times 10^{-5}$ \\
B30-3 & 0.9828 & 0.004566 & 1.2873 & $-2.99 \times 10^{-5}$ \\
B30-5 & 0.9840 & 0.004569 & 1.2950 & $-3.17 \times 10^{-5}$ \\
B30-10 & 0.9834 & 0.004341 & 1.3066 & $-2.92 \times 10^{-5}$ \\
S10-3 & 0.9852 & 0.005246 & 1.2873 & $-8.94 \times 10^{-5}$ \\
S10-5 & 0.9842 & 0.005015 & 1.2890 & $-2.54 \times 10^{-5}$ \\
S10-10 & 0.9852 & 0.005511 & 1.2680 & $-2.77 \times 10^{-5}$ \\
S20-3 & 0.9854 & 0.004044 & 1.3083 & $-3.37 \times 10^{-5}$ \\
S20-5 & 0.9791 & 0.004133 & 1.3103 & $-3.05 \times 10^{-5}$ \\
S20-10 & 0.9806 & 0.003439 & 1.3400 & $-3.30 \times 10^{-5}$ \\
S30-3 & 0.9856 & 0.004762 & 1.2936 & $-2.45 \times 10^{-5}$ \\
S30-5 & 0.9862 & 0.004538 & 1.2896 & $-2.89 \times 10^{-5}$ \\
S30-10 & 0.9850 & 0.004475 & 1.3030 & $-2.65 \times 10^{-5}$ \\
OD & 0.9859 & 0.004230 & 1.2905 & $-3.12 \times 10^{-5}$ \\
\hline & & & &
\end{tabular}

levels. Rawson et al. (2011) obtained the similar results that the increasing ultrasound power level did not decrease the total carotenoid retention levels directly. Conversely, Wang et al. (2018) indicated that the retention levels of $\beta$-carotene increased with increasing ultrasound power. Koca et al. (2007) stated in their study that, inactivation of peroxidase activity for blanched samples resulted in higher $\beta$-carotene content. Lipoxygenase with the peroxidase are major enzymes that are responsible for carotenoid degradation, and these enzymes might be activated at temperature around $60^{\circ} \mathrm{C}$ (Hiranvarachat et al. 2011). Depending on the mentioned effect, the $\beta$-carotene content of the samples might have been decreased; however enzyme activity should be tested in further studies to prove this theory. For the ultrasonic bath pretreatment at $20^{\circ} \mathrm{C}$ and $30^{\circ} \mathrm{C}$, $\beta$-carotene content was significantly increased with increasing process time $(\mathrm{p}<0.05)$. For the soaking in water pretreatment at $20^{\circ} \mathrm{C}$, increasing process time increased the average $\beta$-carotene contents of the samples significantly $(\mathrm{p}<0.05)$. At the same pretreatment conditions, solid loss $\%$ was increased significantly $(\mathrm{p}<0.05)$, although further correlation was not tested relating the solid loss with $\beta$-carotene loss to water.

\section{REHYDRATION RATIO}

Rehydration is an important quality parameter for dry food products and rehydration ability of the product is directly affected from drying procedure and/or pretreatments that are applied before drying. At the beginning of rehydration moisture absorption is rapid and decreases at later stages. The rehydration ratios of carrot slices at the end of the rehydration period ( $4^{\text {th }}$ hour) are shown in Table III. Although the rehydration experiments were carried out for $4 \mathrm{~h}$ in total and the change in weight was lower than $2 \%$ between $3^{\text {rd }}$ and $4^{\text {th }}$ hour, therefore the results of the final rehydration period were presented in Table III. For the same pretreatment method, most of the samples were in the same group with respect to on the pretreatment time $(\mathrm{p}>0.05)$. However, increasing the pretreatment time for P85, significantly increased the rehydration ability of the dried carrot slices $(p<0.05)$. Same effect of ultrasound was observed in the study of Ricce et al. (2016). They also studied on carrot drying and stated that pretreated samples with two pretreatment times had higher rehydration capacity than untreated for drying at 40 and $60^{\circ} \mathrm{C}$. The lowest rehydration ratio was found for the sample treated with ultrasonic 
TABLE VII

Color values of samples.

\begin{tabular}{|c|c|c|c|c|c|}
\hline Sample & $\mathbf{L}^{*}$ & $a^{*}$ & $\mathbf{b}^{*}$ & $C^{*}$ & TCD \\
\hline P65-3 & $66.78 \pm 1.10^{\mathrm{b}, \mathrm{c}, \mathrm{d}}$ & $25.58 \pm 0.95^{\mathrm{d}, \mathrm{e}}$ & $32.52 \pm 0.75^{\mathrm{c}, \mathrm{d}}$ & $41.38 \pm 1.18^{\mathrm{c}, \mathrm{d}}$ & $9.71 \pm 0.97^{\mathrm{a}, \mathrm{b}, \mathrm{c}, \mathrm{d}}$ \\
\hline P65-5 & $65.98 \pm 1.68^{\mathrm{b}, \mathrm{c}, \mathrm{d}}$ & $24.79 \pm 1.73^{\mathrm{b}, \mathrm{c}, \mathrm{d}}$ & $29.79 \pm 1.67^{\mathrm{a}, \mathrm{b}, \mathrm{c}}$ & $38.75 \pm 2.39^{\mathrm{a}, \mathrm{b}, \mathrm{c}, \mathrm{d}}$ & $9.95 \pm 0.87^{\mathrm{a}, \mathrm{b}, \mathrm{c}, \mathrm{d}}$ \\
\hline P65-10 & $66.19 \pm 0.93^{\mathrm{b}, \mathrm{c}, \mathrm{d}}$ & $21.73 \pm 2.44^{\mathrm{a}}$ & $28.39 \pm 2.10^{\mathrm{a}}$ & $35.75 \pm 3.13^{\mathrm{a}}$ & $10.86 \pm 1.88^{\mathrm{a}, \mathrm{b}, \mathrm{c}, \mathrm{d}}$ \\
\hline P75-3 & $63.10 \pm 1.79^{\mathrm{b}}$ & $22.82 \pm 2.02^{\mathrm{a}, \mathrm{b}, \mathrm{c}, \mathrm{d}}$ & $28.69 \pm 2.23^{\mathrm{a}, \mathrm{b}}$ & $36.66 \pm 2.59^{\mathrm{a}, \mathrm{b}}$ & $8.41 \pm 1.14^{\mathrm{a}, \mathrm{b}, \mathrm{c}}$ \\
\hline P75-5 & $66.65 \pm 2.01^{\mathrm{b}, \mathrm{c}, \mathrm{d}}$ & $23.86 \pm 0.46^{\mathrm{a}, \mathrm{b}, \mathrm{c}, \mathrm{d}}$ & $30.96 \pm 1.07^{\mathrm{a}, \mathrm{b}, \mathrm{c}, \mathrm{d}}$ & $39.09 \pm 1.12^{\mathrm{a}, \mathrm{b}, \mathrm{c}, \mathrm{d}}$ & $9.82 \pm 1.48^{\mathrm{a}, \mathrm{b}, \mathrm{c}, \mathrm{d}}$ \\
\hline P75-10 & $66.49 \pm 1.63^{\mathrm{b}, \mathrm{c}, \mathrm{d}}$ & $24.4 \pm 1.27^{\mathrm{a}, \mathrm{b}, \mathrm{c}, \mathrm{d}}$ & $32.39 \pm 1.39^{\mathrm{b}, \mathrm{c}, \mathrm{d}}$ & $40.55 \pm 1.83^{\mathrm{b}, \mathrm{c}, \mathrm{d}}$ & $9.33 \pm 1.50^{\mathrm{a}, \mathrm{b}, \mathrm{c}, \mathrm{d}}$ \\
\hline P85-3 & $66.12 \pm 1.97^{\mathrm{b}, \mathrm{c}, \mathrm{d}}$ & $23.6 \pm 2.22^{\mathrm{a}, \mathrm{b}, \mathrm{c}, \mathrm{d}}$ & $29.39 \pm 2.78^{\mathrm{a}, \mathrm{b}, \mathrm{c}}$ & $37.69 \pm 3.47^{\mathrm{a}, \mathrm{b}, \mathrm{c}, \mathrm{d}}$ & $10.44 \pm 0.51^{\mathrm{a}, \mathrm{b}, \mathrm{c}, \mathrm{d}}$ \\
\hline P85-5 & $68.94 \pm 1.37^{\mathrm{d}}$ & $21.87 \pm 1.49^{\mathrm{a}}$ & $28.98 \pm 2.20^{\mathrm{a}, \mathrm{b}, \mathrm{c}}$ & $36.31 \pm 2.42^{\mathrm{a}}$ & $12.80 \pm 1.95^{\mathrm{d}}$ \\
\hline P85-10 & $66.26 \pm 1.19^{\mathrm{b}, \mathrm{c}, \mathrm{d}}$ & $22.06 \pm 1.38^{\mathrm{a}, \mathrm{b}}$ & $29.22 \pm 1.12^{\mathrm{a}, \mathrm{b}, \mathrm{c}}$ & $36.61 \pm 0.30^{\mathrm{a}, \mathrm{b}}$ & $10.32 \pm 0.71^{\mathrm{a}, \mathrm{b}, \mathrm{c}, \mathrm{d}}$ \\
\hline B10-3 & $66.23 \pm 2.41^{\mathrm{b}, \mathrm{c}, \mathrm{d}}$ & $24.21 \pm 0.78^{\mathrm{a}, \mathrm{b}, \mathrm{c}, \mathrm{d}}$ & $31.69 \pm 0.84^{\mathrm{a}, \mathrm{b}, \mathrm{c}, \mathrm{d}}$ & $39.88 \pm 0.87^{\mathrm{a}, \mathrm{b}, \mathrm{c}, \mathrm{d}}$ & $9.20 \pm 2.10^{\mathrm{a}, \mathrm{b}, \mathrm{c}, \mathrm{d}}$ \\
\hline B10-5 & $65.88 \pm 3.34^{\mathrm{b}, \mathrm{c}, \mathrm{d}}$ & $23.19 \pm 0.33^{\mathrm{a}, \mathrm{b}, \mathrm{c}, \mathrm{d}}$ & $29.28 \pm 1.01^{\mathrm{a}, \mathrm{b}, \mathrm{c}}$ & $37.35 \pm 0.95^{\mathrm{a}, \mathrm{b}, \mathrm{c}}$ & $9.93 \pm 2.64^{\mathrm{a}, \mathrm{b}, \mathrm{c}, \mathrm{d}}$ \\
\hline B10-10 & $63.84 \pm 1.04^{\mathrm{b}}$ & $23.74 \pm 0.75^{\mathrm{a}, \mathrm{b}, \mathrm{c}, \mathrm{d}}$ & $28.70 \pm 1.29^{\mathrm{a}, \mathrm{b}}$ & $37.25 \pm 1.47^{\mathrm{a}, \mathrm{b}, \mathrm{c}}$ & $8.60 \pm 0.47^{\mathrm{a}, \mathrm{b}, \mathrm{c}}$ \\
\hline B20-3 & $66.88 \pm 2.02^{\mathrm{b}, \mathrm{c}, \mathrm{d}}$ & $23.65 \pm 0.83^{\mathrm{a}, \mathrm{b}, \mathrm{c}, \mathrm{d}}$ & $29.28 \pm 1.12^{\mathrm{a}, \mathrm{b}, \mathrm{c}}$ & $37.64 \pm 1.39^{\mathrm{a}, \mathrm{b}, \mathrm{c}, \mathrm{d}}$ & $10.76 \pm 1.16^{\mathrm{a}, \mathrm{b}, \mathrm{c}, \mathrm{d}}$ \\
\hline B20-5 & $68.67 \pm 1.03^{\mathrm{c}, \mathrm{d}}$ & $22.95 \pm 0.39^{\mathrm{a}, \mathrm{b}, \mathrm{c}, \mathrm{d}}$ & $30.05 \pm 1.67^{\mathrm{a}, \mathrm{b}, \mathrm{c}}$ & $37.82 \pm 1.57^{\mathrm{a}, \mathrm{b}, \mathrm{c}, \mathrm{d}}$ & $11.96 \pm 1.46^{\mathrm{c}, \mathrm{d}}$ \\
\hline B20-10 & $67.24 \pm 3.04^{\mathrm{b}, \mathrm{c}, \mathrm{d}}$ & $23.48 \pm 1.52^{\mathrm{a}, \mathrm{b}, \mathrm{c}, \mathrm{d}}$ & $28.71 \pm 2.42^{\mathrm{a}, \mathrm{b}}$ & $37.09 \pm 2.78^{\mathrm{a}, \mathrm{b}}$ & $11.59 \pm 2.10^{\mathrm{b}, \mathrm{c}, \mathrm{d}}$ \\
\hline B30-3 & $66.11 \pm 0.71^{\mathrm{b}, \mathrm{c}, \mathrm{d}}$ & $23.15 \pm 0.62^{\mathrm{a}, \mathrm{b}, \mathrm{c}, \mathrm{d}}$ & $30.19 \pm 1.90^{\mathrm{a}, \mathrm{b}, \mathrm{c}}$ & $38.05 \pm 1.87^{\mathrm{a}, \mathrm{b}, \mathrm{c}, \mathrm{d}}$ & $9.65 \pm 0.76^{\mathrm{a}, \mathrm{b}, \mathrm{c}, \mathrm{d}}$ \\
\hline B30-5 & $63.05 \pm 0.44^{\mathrm{b}}$ & $22.65 \pm 1.34^{\mathrm{a}, \mathrm{b}, \mathrm{c}}$ & $29.17 \pm 0.08^{\mathrm{a}, \mathrm{b}, \mathrm{c}}$ & $36.93 \pm 0.76^{\mathrm{a}, \mathrm{b}}$ & $7.68 \pm 0.32^{\mathrm{a}}$ \\
\hline B30-10 & $63.06 \pm 2.49^{b}$ & $22.60 \pm 0.84^{\mathrm{a}, \mathrm{b}, \mathrm{c}}$ & $29.14 \pm 1.18^{\mathrm{a}, \mathrm{b}, \mathrm{c}}$ & $36.88 \pm 0.68^{\mathrm{a}, \mathrm{b}}$ & $7.92 \pm 1.21^{\mathrm{a}}$ \\
\hline S10-3 & $66.65 \pm 1.99^{\mathrm{b}, \mathrm{c}, \mathrm{d}}$ & $24.20 \pm 1.90^{\mathrm{a}, \mathrm{b}, \mathrm{c}, \mathrm{d}}$ & $31.12 \pm 0.80^{\mathrm{a}, \mathrm{b}, \mathrm{c}, \mathrm{d}}$ & $39.42 \pm 1.54^{\mathrm{a}, \mathrm{b}, \mathrm{c}, \mathrm{d}}$ & $9.80 \pm 2.13^{\mathrm{a}, \mathrm{b}, \mathrm{c}, \mathrm{d}}$ \\
\hline S10-5 & $67.05 \pm 3.02^{\mathrm{b}, \mathrm{c}, \mathrm{d}}$ & $22.96 \pm 1.51^{\mathrm{a}, \mathrm{b}, \mathrm{c}, \mathrm{d}}$ & $30.26 \pm 3.75^{\mathrm{a}, \mathrm{b}, \mathrm{c}}$ & $37.98 \pm 3.90^{\mathrm{a}, \mathrm{b}, \mathrm{c}, \mathrm{d}}$ & $11.02 \pm 1.91^{\mathrm{a}, \mathrm{b}, \mathrm{c}, \mathrm{d}}$ \\
\hline S10-10 & $65.74 \pm 1.04^{\mathrm{b}, \mathrm{c}, \mathrm{d}}$ & $22.43 \pm 0.25^{\mathrm{a}, \mathrm{b}, \mathrm{c}}$ & $30.10 \pm 0.66^{\mathrm{a}, \mathrm{b}, \mathrm{c}}$ & $37.54 \pm 0.58^{\mathrm{a}, \mathrm{b}, \mathrm{c}, \mathrm{d}}$ & $9.29 \pm 0.87^{\mathrm{a}, \mathrm{b}, \mathrm{c}, \mathrm{d}}$ \\
\hline $\mathrm{S} 20-3$ & $65.31 \pm 1.84^{\mathrm{b}, \mathrm{c}, \mathrm{d}}$ & $24.85 \pm 1.25^{\mathrm{c}, \mathrm{d}}$ & $31.09 \pm 2.21^{\mathrm{a}, \mathrm{b}, \mathrm{c}, \mathrm{d}}$ & $39.80 \pm 2.32^{\mathrm{a}, \mathrm{b}, \mathrm{c}, \mathrm{d}}$ & $8.84 \pm 1.36^{\mathrm{a}, \mathrm{b}, \mathrm{c}}$ \\
\hline S20-5 & $66.76 \pm 4.61^{b, c, d}$ & $23.72 \pm 1.63^{\mathrm{a}, \mathrm{b}, \mathrm{c}, \mathrm{d}}$ & $31.31 \pm 0.64^{\mathrm{a}, \mathrm{b}, \mathrm{c}, \mathrm{d}}$ & $39.28 \pm 0.83^{a, b, c, d}$ & $9.97 \pm 4.00^{\mathrm{a}, \mathrm{b}, \mathrm{c}, \mathrm{d}}$ \\
\hline S20-10 & $69.77 \pm 2.65^{\mathrm{d}}$ & $21.72 \pm 0.97^{\mathrm{a}}$ & $32.62 \pm 3.66^{\mathrm{c}, \mathrm{d}}$ & $39.19 \pm 2.60^{\mathrm{a}, \mathrm{b}, \mathrm{c}, \mathrm{d}}$ & $12.80 \pm 2.58^{\mathrm{d}}$ \\
\hline $\mathrm{S} 30-3$ & $66.15 \pm 4.32^{\mathrm{b}, \mathrm{c}, \mathrm{d}}$ & $24.25 \pm 0.98^{\mathrm{a}, \mathrm{b}, \mathrm{c}, \mathrm{d}}$ & $31.17 \pm 2.11^{\mathrm{a}, \mathrm{b}, \mathrm{c}, \mathrm{d}}$ & $39.50 \pm 2.20^{\mathrm{a}, \mathrm{b}, \mathrm{c}, \mathrm{d}}$ & $9.79 \pm 2.68^{\mathrm{a}, \mathrm{b}, \mathrm{c}, \mathrm{d}}$ \\
\hline $\mathrm{S} 30-5$ & $63.52 \pm 1.64^{\mathrm{b}}$ & $23.70 \pm 2.60^{\mathrm{a}, \mathrm{b}, \mathrm{c}, \mathrm{d}}$ & $29.34 \pm 1.34^{\mathrm{a}, \mathrm{b}, \mathrm{c}}$ & $37.72 \pm 2.63^{\mathrm{a}, \mathrm{b}, \mathrm{c}, \mathrm{d}}$ & $8.22 \pm 1.19^{\mathrm{a}, \mathrm{b}}$ \\
\hline $\mathrm{S} 30-10$ & $65.54 \pm 2.70^{\mathrm{b}, \mathrm{c}, \mathrm{d}}$ & $23.08 \pm 1.26^{\mathrm{a}, \mathrm{b}, \mathrm{c}, \mathrm{d}}$ & $30.17 \pm 1.15^{\mathrm{a}, \mathrm{b}, \mathrm{c}}$ & $37.99 \pm 1.20^{\mathrm{a}, \mathrm{b}, \mathrm{c}, \mathrm{d}}$ & $9.18 \pm 2.37^{\mathrm{a}, \mathrm{b}, \mathrm{c}, \mathrm{d}}$ \\
\hline OD & $66.22 \pm 2.56^{\mathrm{b}, \mathrm{c}}$ & $28.37 \pm 1.12^{\mathrm{e}}$ & $38.06 \pm 0.09^{\mathrm{e}}$ & $47.48 \pm 0.59^{\mathrm{e}}$ & $10.69 \pm 2.57^{\mathrm{a}, \mathrm{b}, \mathrm{c}, \mathrm{d}}$ \\
\hline FC & $57.59 \pm 0.79^{\mathrm{a}}$ & $23.34 \pm 0.38^{\mathrm{a}, \mathrm{b}, \mathrm{c}, \mathrm{d}}$ & $34.41 \pm 0.53^{\mathrm{e}}$ & $41.58 \pm 0.52^{\mathrm{d}}$ & - \\
\hline
\end{tabular}

${ }^{\mathrm{a}-\mathrm{e}}$ Different superscripts in the same column are significantly different $(\mathrm{p}<0.05)$.

bath at $10^{\circ} \mathrm{C}$ for $5 \mathrm{~min}$. The lower rehydration ability of food materials are related to structural damage and cell shrinkage during pretreatment (Jambrak et al. 2007), although pretreatment, drying and rehydration processes itself may change the rehydration ability as well (Lewicki 1998). When the pretreatment methods were compared individually, the highest rehydration ratio of the ultrasonic probe pretreated samples was found for the $85 \mathrm{~W}$ power independent of the process time.
In addition, no significant difference was observed between $65 \mathrm{~W}$ and $75 \mathrm{~W}$ ultrasound power ( $\mathrm{p}>0.05$ ). For the ultrasonic bath pretreatment, there was no significant difference found when the results were grouped according to the process temperature $(p>0.05)$ and similar results were observed by Fijalkowska et al. (2017) for apple slices which were subjected to ultrasound bath pretreatment prior to drying; however the rehydration ratio increased significantly at $10 \mathrm{~min}$ process time with increasing 
the bath temperature $(\mathrm{p}<0.05)$. Rehydration ratio of the samples soaked in the water was not significantly different depending on the process time. Only the rehydration ratio of samples soaked in water at $10^{\circ} \mathrm{C}$ was increased with increasing the process time. WG and SL \% of these samples were also significantly increased with increasing process time $(\mathrm{p}<0.05)$. Lower soluble solid content might improve the hydration capacity of the carrots as it was stated in the literature (Lewicki 1998).

\section{CONCLUSIONS}

Carrot samples were subjected to the ultrasonic pretreatment before air drying in a laboratory type tray dryer and drying kinetics and thin layer modelling data was obtained. Quality parameters of dried carrots including color change, $\beta$-carotene content and rehydration ratio was also assessed. Depending on the pretreatment period, ultrasonic application increased the effective diffusion coefficients and decreased the drying time significantly $(\mathrm{p}<0.05)$. However, the solid loss and water gain increased during the pretreatments. Samples pretreated with ultrasonic bath and ultrasonic probe had higher drying rates and lower drying time compared to the sample without pretreatment, which was also consistent with the previously explained bubble collapse and the cavitation effect of ultrasound. Midilli et al. thin layer drying model was determined as the best model expressing the thin layer drying behavior of pretreated carrot slices, although the other models gave satisfactory results too.

In addition to having higher rehydration abilities, ultrasonic pretreatment increased the whiteness, while reducing the yellowness, and had no significant effect on the redness $(p>0.05)$. Therefore, we can conclude that the ultrasonic pretreatment prevented carrots from browning during drying. All pretreated and dried carrot slices had significantly higher $\beta$-carotene content compared to the sample dried without any pretreatment $(p<0.05)$. Correlation between the ultrasonic pretreatments and other quality parameters or different drying techniques may be tested in further studies.

\section{ACKNOWLEDGMENTS}

This study was financially supported by Ege University Scientific Research Projects Commission with the project no: 13-MUH-019.

\section{AUTHOR CONTRIBUTIONS}

BY, HC and ST planned the experimental design. BY has performed the experimental analyses. $\mathrm{BY}$ and $\mathrm{HC}$ both implemented the mathematical model fitting and validate the results. ST and HC supervised the findings of this work. All authors discussed the results and contributed to the writing of final manuscript.

\section{REFERENCES}

ABANO EE, SAM-AMOAH LK AND BART-PLANGE A. 2013. Variation in ultrasonic frequency and time as pre- to air-drying of carrot. J Agric Eng 43(4): 149-158.

AGHBASHLO M, KIANMEHR MH, KHANI S AND GHASEMI M. 2009. Mathematical modelling of thinlayer drying of carrot. Int Agrophys 23: 313-317.

BARBOSA-CÁNOVAS GV AND VEGA-MERCADO H. 1996. Dehydration mechanisms. In: Dehydration of Foods, New York, Springer, p. 101-155.

DOYMAZ I. 2004. Convective air drying characteristics of thin layer carrots. J Food Eng 61: 359-364.

FENG H, BARBOSA-CÁNOVAS GV AND WEISS J. 2011. Ultrasound Technologies for Food and Bioprocessing, New York, Springer, $665 \mathrm{p}$.

FERNANDES FA, LINHARES JR FE AND RODRIGUES S. 2008. Ultrasound as pre-treatment for drying of pineapple. Ultrason Sonochem 15(6): 1049-1054.

FIJALKOWSKA A, NOWACKA M, WIKTOR A AND WITROWA-RAJCHERT SD. 2016. Ultrasound as a pretreatment method to improve drying kinetics and sensory properties of dried apple. J Food Process Eng 39: 256-265.

FIJALKOWSKA A, NOWACKA M AND WITROWARAJCHERT D. 2017. The physical, optical and reconstitution properties of apples subjected to ultrasound before drying. Ital J Food Sci 29: 343-356.

GARCÍA-NOGUERA J, OLIVEIRA FIP, GALLAO MI, WELLER CL, RODRIGUES S AND FERNANDES 
FAN. 2010. Ultrasound-assisted osmotic dehydration of strawberries: effect of pretreatment time and ultrasonic frequency. Drying Technol 28: 294-303.

GARCÍA-PÉREZ JV, CÁRCEL JA, BENEDITO J AND MULET A. 2007. Power ultrasound mass transfer enhancement in food drying. Food Bioprod Process 85(3): 247-254.

GARCÍA-PÉREZ JV, OZUNA C, ORTUÑO C, CÁRCEL JA AND MULET A. 2011. Modeling ultrasonically assisted convective drying of eggplant. Drying Technol 29(13): 1499-1509.

GHAZANFARI A, EMAMI S, TABIL LG AND PANIGRAHI S. 2006. Thin-layer drying of flax fiber: II. Modeling drying process using semi-theoretical and empirical models. Drying Technol 24(12): 1637-1642.

HIRANVARACHAT B, DEVAHASTIN S AND CHIEWCHAN N. 2011. Effects of acid pretreatments on some physicochemical properties of carrot undergoing hot air drying. Food Bioprod Process 89(2): 116-127.

JAMBRAK AR, MASON TJ, PANIWNYK L AND LELAS V. 2007. Accelerated drying of button mushrooms, brussels sprouts and cauliflower by applying power ultrasound and its rehydration properties. J Food Eng 81(1): 88-97.

KARIM MA AND HAWLADER MNA. 2005. Drying characteristics of banana: theoretical modelling and experimental validation. J Food Eng 70(1): 35-45.

KEK SP, CHIN NL AND YUSOF YA. 2013. Direct and indirect power ultrasound assisted preosmotic treatments in convective drying of guava slices. Food Bioprod Process 91(4): 495-506.

KOCA N, BURDURLU HS AND KARADENIZ F. 2007. Kinetics of colour changes in dehydrated carrots. J Food Eng 78(2): 449-455.

KOWALSKI SJ, SZADZIŃSKA J AND ŁECHTAŃSKA J. 2013. Non-stationary drying of carrot: effect on product quality. J Food Eng 118(4): 393-399.

KUCUK H, MIDILLI A, KILIC A AND DINCER I. 2014. A review on thin-layer drying-curve equations. Drying Technol 32: 757-773.

LEWICKI PP. 1998. Effect of pre-drying treatment, drying and rehydration on plant tissue properties: a review. Int J Food Prop 1(1): 1-22.

LEWIS WK. 1921. The rate of drying of solid materials. J Ind Eng Chem 13(5): 427-432.

LI Z, RAGHAVAN GS AND WANG N. 2010. Carrot volatiles monitoring and control in microwave drying. LWT-Food Sci Technol 43(2): 291-297.

MASON TJ, RIERA E, VERCET A AND LOPEZ-BUESA P. 2005. Application of ultrasound. In: Emerging Technologies for Food Processing, Elsevier Academic Press, The Netherlands, p. 323-351.

MAYOR L AND SERENO AM. 2004. Modelling shrinkage during convective drying of food materials: a review. J Food Eng 61(3): 373-386.

MIDILLI A, KUCUK H AND YAPAR Z. 2002. A new model for single layer drying. Drying Technol 20: 1503-1513.
NIH. 2014. U.S. Department of Health \& Human Services National Institutes of Health. NIH, National Institutes of Health Home Page, https:/ods.od.nih.gov/factsheets/ VitaminA-Consumer/ (Accessed 07 October 2014).

NOWACKA M, WIKTOR A, ŚLEDŹ M, JUREK N AND WITROWA-RAJCHERT D. 2012. Drying of ultrasound pretreated apple and its selected physical properties. J Food Eng 113(3): 427-433.

ORTUÑO C, PÉREZ-MUNUERA I, PUIG A, RIERA E AND GARCÍA-PEREZ JV. 2010. Influence of power ultrasound application on mass transport and microstructure of orange peel during hot air drying. Phys Procedia 3(1): 153-159.

PAGE GE. 1949. Factors influencing the maximum rate of air drying shelled corn in thin-layers. M.S.Thesis, Purdue University, West Lafayette, Indiana. (Unpublished).

PERRY RH AND GREEN D. 1997. W. Perry's Chemical Engineers' Handbook, New York: Mc GrawHill.

RANGANNA S. 1986. Handbook of analysis and quality control for fruit and vegetable Products, New Delhi: Tata McGraw-Hill Education.

RAWSON A, TIWARI BK, TUOHY MG, O'DONNELL CP AND BRUNTON N. 2011. Effect of ultrasound and blanching pretreatments on polyacetylene and carotenoid content of hot air and freeze dried carrot discs. Ultrason Sonochem 18(5): 1172-1179.

RICCE C, ROJAS ML, MIANO AC, SICHE R AND AUGUSTO PED. 2016. Ultrasound pretreatment enhances the carrot drying and rehydration. Food Res Int 89: 701-708.

SONMETE MH, MENGES HO, ERTEKIN C AND OZCAN MM. 2017. Mathematical modeling of thin layer drying of carrot slices by forced convection. J Food Meas Charact 11(2): 629-638.

SORIA AC AND VILLAMIEL M. 2010. Effect of ultrasound on the technological properties and bioactivity of food: a review. Trends Food Sci Technol 21(7): 323-331.

STOJANOVIC J AND SILVA J. 2007. Influence of osmotic concentration, continuous high frequency ultrasound and dehydration on antioxidants, colour and chemical properties of rabbiteye blueberries. Food Chem 101(3): 898-906.

USDA. 2014. National Nutrient Database for Standard Reference. U.S. Department of Agriculture. USDA, Nutrient Data Laboratory Home Page, http://ndb.nal.usda. gov/ndb/search/list (Accessed 24 June 2014).

WANG L, XU B, WEI B AND ZENG R. 2018. Low frequency ultrasound pretreatment of carrot slices: Effect on the moisture migration and quality attributes by intermediatewave infrared radiation drying. Ultrason Sonochem 40:619-628.

ZIELINSKA M AND MARKOWSKI M. 2010. Air drying and moisture diffusivity of carrots. Chem Eng Process 49: 212-218. 